\title{
The Impact of Indirect Taxation on the Plantation Sector in Indonesia
}

\author{
Dhani Setyawan \\ Center for Climate Change Financing and Multilateral Policy \\ Fiscal Policy Office-Ministry of Finance of Indonesia \\ dhanisetyawan83@gmail.com
}

\begin{abstract}
This study attempts to analyze the impact of the indirect taxes levy on the plantation sector in Indonesia. The aim of this study is to investigate the assumptions that the disincentive fiscal policy could generate some trade offs against some other economic variables i.e. National GDP level, Domestic Prices, total Exports and Imports, Poverty Rates, Government Revenues and Government Consumption Expenditures. This study employs the inter-regional CGE model with bottom-up approach and applying the Indonesian Social Accounting Matrix. The empirical results showed that, overall the disincentive fiscal policy in the plantation sector could give positive impacts not only to the area of the production forest sector, but also to the increasing number of the natural forest area in Indonesia. However, the implementation of this policy has some trade offs against some other economic variables.
\end{abstract}

Keywords: Indirect Tax Policy, Plantation Sector, GDP, Indonesia.

\section{Introduction}

The implementation of regional autonomy in Indonesia nowadays is a part of the decentralization process. Regional autonomy aligned with the enactment of Law No. 32 of 2004 on Local Government and Law No. 33 of 2004 on Central and Local Fiscal Balance. In the autonomy era, the local governments are expected to be more assured in exploring their financial resources in order to finance both local needs and local developments (Machfud, 2005). Nevertheless, the implementation of regional autonomy for some government apparatus seemingly defined as the efforts to increase local own revenue through provision of local regulations. Some people said that the issuance of local regulations often disregard the basic principles and the philosophy of taxes and retribution (BI, 2007). Many tax and retribution regulations constituted by the local government were revoked by the central government due to contravene with the higher legislation (MOHA, 2011). In the year 2009, approximately 2106 drafts (from total 4858 drafts evaluated) of local regulations regarding tax and retributions were called off by the central government, since it were pondered as disruption for the local investment development, as well as causing high cost economy (DGFB, 2012). Those aforementioned problems already anticipated through Law No. 34 of 2000 regarding Local government taxes and retribution, denoted in article 2, paragraph (4) that the objects of local tax levied is different from the central tax levied. However, the over power of the local government in constituting different taxes and retributions induce bad impact to the communities and business endeavour activities. Therefore, to overcome those problems, the central government enact Law No. 28 of 2009 in order to enforce a more definite authority for the local governments in terms of taxing criterias. One of the subject matters set forth in the Law No. 28/2009 is about the land and building tax for rural and urban areas. The law is granting the local government to have full authorization in imposing the land and building tax. By transferring such authority to the local government, the central government expect that the local own revenue will increase augmentedly (MOF, 2009). In addition to those policies, the central government also has another discourse to impose indirect tax on plantation which the subject matters currently part of the central government authority. Imposition of indirect tax on plantation aims to reduce encroachment of natural forest. It is based on the anxieties that the reduction of natural forests area currently is a result of the augmenting expansion of plantation sector as appeared in Sumatera, Kalimantan and Papua regions. This study attempts to analyze the impact of the indirect taxes levy on the plantation sector. The expansionary levy objects of indirect tax plantation designates expectedly to increase state budget income from the taxation sector. Though, in some extent the impact of this policy collide with alteration of the public welfare. Based on the aforementioned background, this study was conducted in order to provide different kind scenarios of the indirect tax policy impact which (1) imposed by the central government or (2) imposed by the local government. 


\section{Literature Review}

CGE models in Indonesia have been developed since the late 1980s. Those models largely pertained in CGE Static which employed Input-Output table (table I-0) data source, as well as the Indonesia SAM Table. CGE model developed by Lewis (1991) was one of the first CGE model in Indonesia. This model utilizing Indonesia Table I-O of 1985. The Model can measure the alteration affects of value added tax upon the economic sectors in Indonesia. Another model from Abimanyu (2000), which so-called Indorani CGE model had considered some environmental variables such as NO2, CO, SO2, SPM and BOD to examine the impact of trade policies on the environment. The financial CGE Model generated by Azis (2000) is a model that incorporates financial sectors and real sectors of the Indonesian economy. The real sector adopted in this model was a refinement of the Lewis model (1991), while the financial sector was adopted from Thorbecke model (1992). The model utilized a specific of SAM financial sector, which aimed to look at the impact of the financial crisis upon the income of the household sector. To the best of our knowledge only a limited number of studies in Indonesia has, thus far, related the issue of tax policy reforms utilizing CGE model, therefore this study attempts to enrich some of those studies above. In the international context, computable general equilibrium models have frequently been applied to measure the tax reform impact on the macroeconomic, as argued in the literature review of Piggott and Whalley. Piggott and Whalley (2001) build simple quantitative cases of general equilibrium economy, whereas the extending VAT component cuts down welfare due to supply side variations towards the home production. Consequences from adjustment of the model demonstrate that the extending component of VAT has diluted the aggregate efficiency. Boccanfuso, et al (2011) depicted that by contending budget neutrality with less taxation level than the one laid in the finance act; re-instituting VAT neutrality by enlarging the tax base alters economic intricacy and raises the household welfare considered to the initial condition. When they refuses the concept of budget neutrality and reinstates the VAT, they pointed that the sudden VAT increment results to a substantial loss in reallocation, particularly for sectors with a faint ex ante tax burden. In this condition, household welfare diminishes, as inequalities. McLure (2003) describes characteristics of a well designed indirect tax program in the case of Canada. He indicates some contrary results coming from inefficient indirect taxation i.e. difference tax regime on taxation of consumers on goods and services has adverse impacts for economic neutrality. In addition to that domestic producers also bear competitive disadvantage in the absence of destination based taxation principle. Dixon and Rimmer (1999) employ a general equilibrium model to examine the affect of Australia's tax reforms. They concluded that the longrun resource share benefits coming from the projected tax varies will be negligible i.e. Terms-of-trade result would be negative, as well as composition of exports would alter away from services and in favour of goods.

\section{Methodology}

This study employs a CGE model (Computable General Equilibrium) developed by Resosudarmo, et al (2009) which so-called Inter-Regional of System Analysis for Indonesia-5 Regions (IRSA-INDONESIA 5). This model represent inter regional CGE with bottom-up approach and exerting the Indonesian Social Accounting Matrix (SAM) table base calculation. The association amongst inputs and outputs in this model is validated through a nested CES-Leontief production function in each production sector. The structure of the production function is similar for all sectors. The data structure applied in this model divided into five regions i.e. Sumatera region, Java-Bali region, Kalimantan region, Sulawesi region and East Indonesia region. Each region fractioned into 35 production sectors i.e. classification of labor (16 sectors, comprise of: skilled/unskilled labour, formal/informal labour), classification of non-labour (accounts for capital and land), classification of house hold (rural and urban households), and other institutions such as local governments and corporate enterprise. This model carry out optimization calculation at the regional level, while the national result is an aggregation of the regional results. By employing SAM basis calculation, the model takes into account inter-regional trade flow, flow of primary factors and inter-regional institutional transfer. As for the solver software utilized in this model is Generalized Algebraic Modeling System (GAMS). Inter regional CGE is an instrument for empiric analysis which entails real data sets requirements. This data is conjecturally representing the economy's general equilibrium which is reckoned as the base result, and lots of the parameters of the model are judged on the assumption basis. In addition, through categorizing the economic variables as endogenous or exogenous, the affect of counterfeit changes in the exogenous variables is broke down in terms of the model result. Therefore, the equilibrium model is applied to measure, systematically and in numeric terms, the tendency of alteration of certain significant interdependent economic variables. 
The Model Structure Concept: The IRSA-Indonesia 5 incorporates numerous sets of equations (Resosudarmo et al, 2009). Because of limited space, only the fundamental concepts of equation will be set forth here. The model of IRSA-Indonesia 5 is utilizing a Linear Expenditure System (LES) model for each commodity in the household demand. The LES model derived from the Stone-Geary utility function to maximize the budget constraint. The composite of imports and domestic products are consumed by household (government and industries) in each region employing a constant elasticity of substitution according to Armington function. The composite of domestic products from different regions have a constant elasticity of substitution. Meanwhile, the sources of household income are coming from production activities of labor and capital in different regions, transfers from other households, transfers from national and regional governments and remittances from overseas. All of the consumptions from household, government and industries developed the system of demand functions. A top-down incomedistributional system is interconnected with the household demand equations that combine each household group in each region into 100 household groups (urban and rural households). The LES demand function obtained from the Stone-Geary utility function is utilized to calculate the expenditure for each of these 100 households. While, the income of these 100 households is measured by a share parameter allotting the income of the original household. A nested production function is also employed in the model for the production side. The Leontief production function is the top level of the production function model for each commodity amongst all intermediate products required for production and the composite of value added. A constant elasticity of substitution (CES) function is required as the composite of value added between capital, labor and land. The CES combination amongst imported and composite domestic goods is utilized for each intermediate good in the production of particular commodity. The constant elasticity of substitution among different domestic goods from all regions is also estimated. In this model, a zero profit condition is counterfeit to portray a fully competitive market. Market clearing requires that all markets for commodities and factors of production are in a state of equilibrium; i.e. supply matches demand (Resosudarmo et al, 2009). At each level of this nested production function, firms maximize their profits for every production functions at each level. Then, firms distribute their products domestically and abroad. The amount of goods sent out abroad or preserved for domestic consumption is determined by the export demand function and domestic demand system. The inter-temporal part of the model comprises mainly of two equations: (1) an equation indicating capital accumulation from one year to the another; and (2), the growth of the country's labour force.

\section{Results and Discussion}

The simulation model developed in this study is focused on the impact of the indirect tax policy upon the plantation sector. The simulation scenario examine the initial conditions before tax policy implementation and afterwards the policy enforced. Those scenario is aimed to conceive the impact of tax policy upon the Indonesian economy. In this study, the Indonesian economy assumed to be equal to the current Indonesian economic condition when the study is made, as well as cateris paribus condition assumption is applied. Scenarios originated can be specified as follows:

- Scenario 1 : The central government impose indirect taxes over the plantation sector by $10 \%$;

- Scenario 2 : All of the local governments impose indirect taxes over the plantation sector by 10 $\%$.

The results of those scenario will be divided into 5 sections, namely: (1) the impact to the land use change; (2) the impact on domestic prices; (3) the impact on the total exports and imports; (4) the impact on GDP and poverty rates; (5) the impact on government revenues and government consumption expenditures.

The Impact to the Land Use: The simulation model showed that (table 1), in general, land use in the plantation sector (ESTCR) decreased significantly, especially in Sumatera (R1). In the scenario 1, the disincentive fiscal policy contribute to the decreasing number of land use in the plantation sector of Sumatera region (R1) by around 378.463 million ha, while in the scenario 2, land use of the plantation sector diminish around 371.530 million ha. On the contrary, land use in the production forests sector (FORES) in Sumatera region increase by 72.074 million ha, as in the scenario 2, the land use of production forest sector only increased by 67.032 million ha. Based on the simulation results, both of those scenarios depicted that, the largest increase of natural forest area (C_NFORAREA) is in Sumatera region (R1). In Sumatera region, the natural forest area is increased significantly by 306.389 million HA (scenario 1), as well as in scenario 2, the natural forest area in Sumatera region also increase by 304.498 million HA. 
Table 1 : The Impact of Tax Policy on Land Use in Indonesia

\begin{tabular}{|c|c|c|c|c|c|c|}
\hline Comodity & 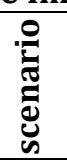 & $\begin{array}{l}\text { R1 } \\
\text { (Sumatera) }\end{array}$ & $\begin{array}{l}\text { R2 } \\
\text { (Jawa) }\end{array}$ & $\begin{array}{l}\text { R3 } \\
\text { (Kalimantan) }\end{array}$ & $\begin{array}{l}\text { R4 } \\
\text { (Sulawesi) }\end{array}$ & $\begin{array}{l}\text { R5 } \\
\text { (East Indonesia) }\end{array}$ \\
\hline \multicolumn{7}{|c|}{ C_LANDAREA } \\
\hline \multirow{2}{*}{ ESTCR } & 1 & -378.4637 & -50.4351 & -133.7818 & -121.2965 & -121.3798 \\
\hline & 2 & -371.5304 & -160.4621 & -115.5221 & -120.8169 & -102.3586 \\
\hline \multirow{2}{*}{ FORES } & 1 & 72.0742 & -0.3115 & 40.9689 & 25.8112 & 27.0050 \\
\hline & 2 & 67.0323 & 5.4325 & 30.9064 & 24.0018 & 15.8696 \\
\hline \multicolumn{7}{|c|}{ C_NFORAREA } \\
\hline Scenario 1 & & 306.3895 & 50.7466 & 92.8130 & 95.4854 & 94.3748 \\
\hline Scenario 2 & & 304.4981 & 155.0296 & 84.6157 & 96.8151 & 86.4890 \\
\hline
\end{tabular}

(In million hectares/ha)

The Impact on Domestic Prices: The imposition of indirect tax on the plantation sector will distressed the producers price level. The low degree of purchasing power in the plantation sector made the bargaining power of plantation commodities also depleted. This condition occurs because, when the farmers sell their products at the normal price level, they will bear some parts of the levied tax (if they do not raise the commodity price).

Table 2: the impact of indirect tax policy on domestic prices

\begin{tabular}{|c|c|c|c|c|c|c|}
\hline $\begin{array}{l}\text { Comodity } \\
\text { Domestic P }\end{array}$ & 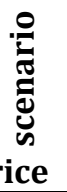 & $\begin{array}{l}\text { R1 } \\
\text { (Sumatera) }\end{array}$ & $\begin{array}{l}\text { R2 } \\
\text { (Jawa) }\end{array}$ & $\begin{array}{l}\text { R3 } \\
\text { (Kalimantan) }\end{array}$ & $\begin{array}{l}\text { R4 } \\
\text { (Sulawesi) }\end{array}$ & $\begin{array}{l}\text { R5 } \\
\text { (East Indonesia) }\end{array}$ \\
\hline \multirow{2}{*}{ PADDY } & 1 & -3.9223 & -0.6944 & -0.1633 & -0.3421 & -0.5008 \\
\hline & 2 & -4.1401 & -1.2136 & -0.1419 & -0.3725 & -0.5594 \\
\hline \multirow{2}{*}{ FOREST } & 1 & -0.5838 & -0.4710 & -0.4343 & -0.5142 & -0.4757 \\
\hline & 2 & -0.6654 & -0.6001 & -0.4912 & -0.6116 & -0.5420 \\
\hline \multirow{2}{*}{ ESTCR } & 1 & 3.4155 & 3.5393 & 3.5670 & 2.4529 & 4.9908 \\
\hline & 2 & 4.4133 & 6.3366 & 4.9875 & 3.1649 & 6.2266 \\
\hline \multirow{2}{*}{ WOODS } & 1 & -0.0479 & 0.0045 & 0.0092 & -0.0624 & -0.0068 \\
\hline & 2 & -0.0509 & -0.0227 & -0.0057 & -0.0606 & -0.0386 \\
\hline \multirow{2}{*}{ FOODB } & 1 & -0.3929 & -0.0891 & -0.1069 & -0.1475 & -0.0300 \\
\hline & 2 & -0.3925 & -0.1389 & -0.1271 & -0.1515 & -0.0688 \\
\hline
\end{tabular}

(In percentage /\%)

The largest decreased of consumer domestic price for paddy commodity (PADDY) is occurred in Sumatera region by $3.92 \%$ (scenario 1 ), and in the scenario 2 , the decreased only reached $4.14 \%$. For plantation sector (ESTCR), the largest consumer domestic price decreased is took place in East Indonesia (R5) by $4.99 \%$ (scenario 1), whereas in the scenario 2, the largest decreased took place in Java (R2) region by $6.33 \%$. In the forestry sector (FOREST), the highest consumer domestic price is both took place in Sumatera (R1) by $0.58 \%$ for scenario 1 and $0.66 \%$ for scenario 2 . While, in the wood industry sector (WOODS) the highest price is occurred in Sulawesi region (R4) by $0.06 \%$ (both scenario 1 and 2). Obviously, the consumer domestic price of plantation sector (ESTCR) augmented because of the indirect tax imposition.

The Impact on the Total Exports and Imports: Heretofore, the price level of indonesian plantation commodity products is still less competitive compare to neighbour countries products. The highly efficient of plantation system and productivity in those countries make its price level less expensive compare to Indonesian products. The imposition of indirect tax on plantation sector will make its commodity price more expensive, which can lead to the declining of the competitiveness of the plantation 
products. This condition also portrayed by Dixon and Rimmer (1999) that broadening $10 \%$ of indirect tax would effect negatively to the terms of trade and alter the composition of exports.

Table 3: The Impact on the Total Exports and Imports

\begin{tabular}{lcll}
\hline Comodity & scenario & Export & Import \\
\hline \multirow{2}{*}{ PADDY } & $\mathbf{1}$ & 3.0430 & -3.2466 \\
& $\mathbf{2}$ & 3.1325 & -5.3922 \\
FOREST & $\mathbf{1}$ & 2.7821 & -0.5969 \\
& $\mathbf{2}$ & 3.2051 & -0.7168 \\
ESTCR & $\mathbf{1}$ & -16.4735 & 8.9787 \\
& $\mathbf{2}$ & -21.2518 & 13.4757 \\
WOODS & $\mathbf{1}$ & 0.0500 & 0.4400 \\
& $\mathbf{2}$ & 0.1163 & 0.3313 \\
FOODB & $\mathbf{1}$ & 0.9719 & -0.3838 \\
& $\mathbf{2}$ & 1.0985 & -0.5091 \\
\hline
\end{tabular}

(In percentage / \%)

In scenario 1 , the largest declines of national export commodity occurred in the plantation sector by $16.47 \%$ (ESTCR), while the largest increases occurred in the export of paddy sector by $3.04 \%$ (PADDY). On the other hand, the declining of the plantation export commodity is followed with the increasing of the plantation (ESTCR) export commodity by $8.98 \%$, while the paddy sector (PADDY) decreases by $3.24 \%$. Likewise in scenario 1, in scenario 2, the export level of the plantation sector (ESTCR) also decreased by $21.25 \%$, which followed with the increasing of the import for plantation sector by $13.47 \%$.

The Impact on GDP and Poverty Rates: The largest share of Indonesian GDP is come from the plantation sector. From this view, it can be ascertained that the majority occupation of the Indonesian society is farmers. Therefore, some people judge the raising of indirect tax imposition to the farmers could lead to iniquity. On the one hand, the imposition would increase the goverment revenue, but on the other hand, it would lower the level of the farmers' welfare which can also bring down the society welfare. Emran and Stiglitz (2004) depicted that indirect tax reform base broadening with a revenueneutral reduction in trade taxes might diminish welfare.The indirect tax imposition will disrupt the economic stability which can increase the level of the poverty rates. This condition can be seen from simulation results below.

Table 4: The Impact on GDP and Poverty Rates

\begin{tabular}{|c|c|c|c|c|c|c|c|}
\hline Comodity & 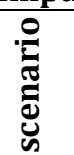 & National & $\begin{array}{l}\text { R1 } \\
\text { (Sumatera) }\end{array}$ & $\begin{array}{l}\text { R2 } \\
\text { (Jawa) }\end{array}$ & $\begin{array}{l}\text { R3 } \\
\text { (Kalimantan) }\end{array}$ & $\begin{array}{l}\text { R4 } \\
\text { (Sulawesi) }\end{array}$ & $\begin{array}{l}\text { R5 } \\
\text { (East Indonesia) }\end{array}$ \\
\hline \multirow{2}{*}{ GDP } & 1 & -0.0416 & -0.1888 & 0.0198 & -0.0374 & -0.2756 & 0.0888 \\
\hline & 2 & -0.0563 & -0.0485 & -0.0631 & -0.0088 & -0.1011 & 0.0047 \\
\hline Poverty & 1 & 17.3920 & 18.9498 & 16.4019 & 11.5643 & 19.0655 & 30.4729 \\
\hline Incidence & 2 & 17.4355 & 18.8235 & 16.5014 & 11.5004 & 18.9496 & 30.9481 \\
\hline
\end{tabular}

(In percentage /\%)

From the scenario 1 , the National GDP level decreased by $0.041 \%$, while in scenario 2 , the National GDP level decreased deeper by $0.056 \%$. From both scenario 1 and 2, the Sulawesi region (R4) experienced the highest GDRP decreases by $0.275 \%$ and $0.101 \%$. Nationally in scenario 1 and 2 , the poverty incidence level increase by $17.4 \%$ with the highest increases occurred in the East Indonesia region (R5) by $30.5 \%$ (scenario 1) and $30.9 \%$ (scenario 2).

The Impact on Government Revenues and Government Consumption Expenditures: From the scenario 1, national government revenue (Gov't Revenue) increased by $3.55 \%$, while in the scenario 2 , government revenue only increased by $0.16 \%$. The decreasing of the total government revenue in 
scenario 2 occurred, because some part of the tax revenue is apportioned to the local government (In the scenario 2, the local governments levy their own indirect taxes). The east Indonesia region (R5) experienced the largest increasing of government revenue by $3.04 \%$, which is supported, by the increasing of domestic prices of the east Indonesia plantation sector

Table 5: The Impact on Government Revenues and Government Consumption Expenditures

\begin{tabular}{|c|c|c|c|c|c|c|c|}
\hline Comodity & 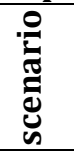 & National & $\begin{array}{l}\text { R1 } \\
\text { (Sumatera) }\end{array}$ & $\begin{array}{l}\text { R2 } \\
\text { (Jawa) }\end{array}$ & $\begin{array}{l}\text { R3 } \\
\text { (Kalimantan) }\end{array}$ & $\begin{array}{l}\text { R4 } \\
\text { (Sulawesi) }\end{array}$ & $\begin{array}{l}\text { R5 } \\
\text { (East Indonesia) }\end{array}$ \\
\hline Gov't & 1 & 3.5477 & 0.6364 & 1.0272 & 1.0020 & 0.5506 & 3.0443 \\
\hline Revenue & 2 & 0.1559 & 5.6238 & 1.4660 & 3.3553 & 3.5622 & 2.0633 \\
\hline Gov't & 1 & 3.2351 & 0.4608 & 0.7756 & 0.3875 & 0.4098 & 2.3323 \\
\hline Consump & 2 & -0.4428 & 4.4095 & 1.2298 & 2.3235 & 2.6731 & 1.7154 \\
\hline
\end{tabular}

(In percentage /\%)

Likewise the government revenue, in the scenario 1, the government consumption (Gov't Consump) also increased by $3.23 \%$, but when the tax levies authority handed over to the local governments (scenario 2), the government consumption decline into $0.44 \%$. This condition is reasonable, since the decreasing of the central government revenue will be certainly followed with the decreasing amount of the central government consumption.

\section{Conclusion}

Overall, the disincentive fiscal policy in the plantation sector could give positive impacts not only to the area of the production forest sector, but also to the increasing number of the natural forest area in Indonesia. However, this policy has some tradeoffs against some other economic variables. Some of the trade offs are:

A. Trade offs from the $10 \%$ indirect taxes imposition conducted by the central government.

- National GDP level decreased by $0.041 \%$, with the highest GDRP decreases occured in the Sulawesi region by $0.275 \%$;

- The poverty incidence level increase by $17.4 \%$ with the highest increases occured in the East Indonesia region by $30.5 \%$;

- However, this policy generate positive impacts for the increasing amount of the central government revenue by $3.55 \%$, which also followed with the increasing amount of central government consumption by $3.23 \%$.

B. Trade offs from the $10 \%$ indirect taxes imposition conducted by all of the local governments.

- National GDP level decreased by $0.056 \%$, with the highest GDRP decreases occured in the Sulawesi region by $0.101 \%$;

- The poverty incidence level increase by $17.4 \%$ with the highest increases occured in the East Indonesia region by $30.9 \%$;

- There is a significant difference of central government revenue compared to the scenario 2 , whereas in scenario 2 , the central government revenue only increased by $0.156 \%$. This condition assumed to be occured because the central government is no longer enjoying the tax revenue from plantation, since the tax levies authority is already handed over to the local governments.

Those above trade offs are normally encountered as implications of conducting one policy. In our view, sound policy involves a mix of good analytic thinking and pragmatism. Therefore, a substantially cost and benefit analysis is needed to provide the best policy in terms of finding out whether the impact of one policy can generate and optimizing the welfare of the society. Empirical experts can't do their works unless they base their work in applicable theoretical principles that are distinctly stated and subject to scrutiny. In addition to that, recognizing factors that leave quantification with at least some viewpoint to their qualitative emphasis. A sound strategy is to estimate tangibles cautiously, considering administrative/program costs. Simplistic models cannot be employed to produce accurate, wellgrounded standards of the costs and benefits of programs and policies. For the highest extent potential, policy maker should distinguish intangible changes in economy and anticipate their potential implications for efficient and effective policy design. 
Acknowledgement: This study could not be completed without encouragement and support from Arief Anshory Yusuf (Padjajaran University) and all friends from Padjajaran University who kindly assisting me in the CGE simulation process.

\section{References}

Abimanyu, A. (2000). Impact of Agriculture Trade and Subsidy Policy on the Macro economy, Distribution, and Environment in Indonesia: A Strategy for Future Industrial Development Developing Economies.

Azis, I. J. (2000). Simulating Economy-Wide Models to Capture the Transition from Financial Crisis to Social Crisis, the Annals of Regional Science.

Bank of Indonesia-BI. (2007). Kajian Identifikasi Peraturan Pusat dan Peraturan Daerah Dalam Rangka Pengembangan Usaha Mikro, Kecil dan Menengah, Bank of Indonesia Credit Bureau. Ministry of Home Affairs-MOHA, Revisi Undang-Undang Nomor 32 Tahun 2004 tentang Pemerintahan Daerah, Naskah Akademik (2011).

Boccanfuso, D., Quatrebarbes, C. \& Luc, S. (2011). Can the removal of VAT Exemptions support the Poor? The Case of Niger, CERDI, Etudes et Documents.

Directorate General of Fiscal Balance-DGFB. (2012). Perkembangan Evaluasi PERDA tentang Pajak Daerah dan Retribusi Daerah Tahunan, Status Perda Raperda (5 Maret 2012)

Dixon, P. B. \& Rimmer, M. T. (1999). The Government's Tax Package: Further Analysis based on Monash Model. General Paper No. G-131, Center of Policy Studies, Monash University.

Emran, M. S. \& Stiglitz, J. E. (2004). On selective indirect tax reform in developing countries. Journal of Public Economics, 2, 599-623.

Lewis, J. D. (1991). A Computable General Equilibrium (CGE) Model of Indonesia. HIID Series of Development Discussion Papers, 378.

Machfud, S. (2005). Optimalisasi Pajak Daerah Dan Retribusi Daerah Dalam Rangka Meningkatkan Kemampuan Keuangan Daerah, 5th edition, Yogyakarta: www.kanisiusmedia.com.

McLure, C. E. (2003). Harmonising the RSTs and GST: Lessons from Canada from Canadian Experience Hoover Institution, Stanford University.

Ministry of Finance-MOF. (2009). Pokok-pokok Pengaturan Undang-Undang Pajak Daerah dan Retribusi Daerah Press Release MOF, (18 Agustus 2009).

Piggott, J. \& Whalley, J. (2001). VAT base broadening, self supply, and the informal sector. American Economic Review, 3, 1084-1094.

Republic of Indonesia. (2004). Law of the Republic of Indonesia No. 32 of 2004 on Local Government. Undang-Undang Republik Indonesia Nomor 32 Tahun 2004 Tentang Pemerintahan Daerah.

Republic of Indonesia. (2004). Law of the Republic of Indonesia No. 33 of 2004 on Central and Local Fiscal Balance. Undang-Undang Republik Indonesia Nomor 33 Tahun 2004 Tentang Perimbangan Keuangan Antara Pemerintah Pusat DanPemerintah Daerah

Republic of Indonesia. (2000). Law of the Republic of Indonesia No. 34 of 2000 on Revision of Law No 18 of 1997 regarding Local Taxes and Retribution. Undang-Undang Republik Indonesia Nomor 34 Tahun 2000 Tentang Perubahan Atas Undang-Undang Republik Indonesia Nomor 18 Tahun 1997 tentang Pajak Daerah dan Retribusi Daerah.

Republic of Indonesia. (2009). Law of the Republic of Indonesia No. 28 of 2009 on Local Taxes and Retribution. Undang-Undang Republik Indonesia Nomor 28 Tahun 2009 Tentang Pajak Daerah dan Retribusi Daerah

Resosudarmo, B. P., Yusuf, A. A., Djoni, H. \& Nurdianto, L. (2009). Implementation of the IR-CGE Model for Planning: IRSA-INDONESIA 5 (Inter-Regional System of Analysis for Indonesia in 5 Regions), CSIRO.

Thorbecke, E. (1992). Adjustment and Equity in Indonesia, OECD Publications, Paris. 